International Journal of Engineering \& Technology, $7(3.2)(2018) 398-400$
International Journal of Engineering \& Technology
SPC
Website: www.sciencepubco.com/index.php/IJET
Research paper

\title{
Design of Composite Skin Panels with Solar Panels on the Roof
}

\author{
Serhiy Shkirenko ${ }^{1}$, Volodymyr Muravlov ${ }^{2}$, Oleksandr Zyma ${ }^{3}$ \\ ${ }^{I}$ Poltava National Technical Yuri Kondratyuk University, Ukraine \\ ${ }^{2}$ Poltava National Technical Yuri Kondratyuk University, Ukraine \\ ${ }^{3}$ Poltava National Technical Yuri Kondratyuk University, Ukraine \\ *Corresponding Author E-Mail: Net69ten@Gmail.Com
}

\begin{abstract}
\section{Introduction}

Nowadays in Ukraine a usage of solar panels becomes popular. Solar panels are installed differently according to their geographic locations throughout the world. The ideal situation is when the sun is hitting the panels at a perfectly perpendicular angle $\left(90^{\circ}\right)$. This maximizes the amount of energy striking the panels and being produced. Such an angle is controlled by the two factors - the orientation (North/South/East/West) and the angle of the panels from the Earth surface. A common myth is that solar panels do not work during winter. The white snow can reflect light and help improve PV performance. Winter will only hurt solar production if the panels are covered with snow. All solar panels are designed to bear a certain amount of weight - and snow will usually not be heavy enough to cause issues.
\end{abstract}

An example of typical two-sided composite (timber and plywood) skin panel design to be used as a roof member with solar panels.

Keywords: solar panels; roof members; two-sided composite skin panel; design of building constructions.

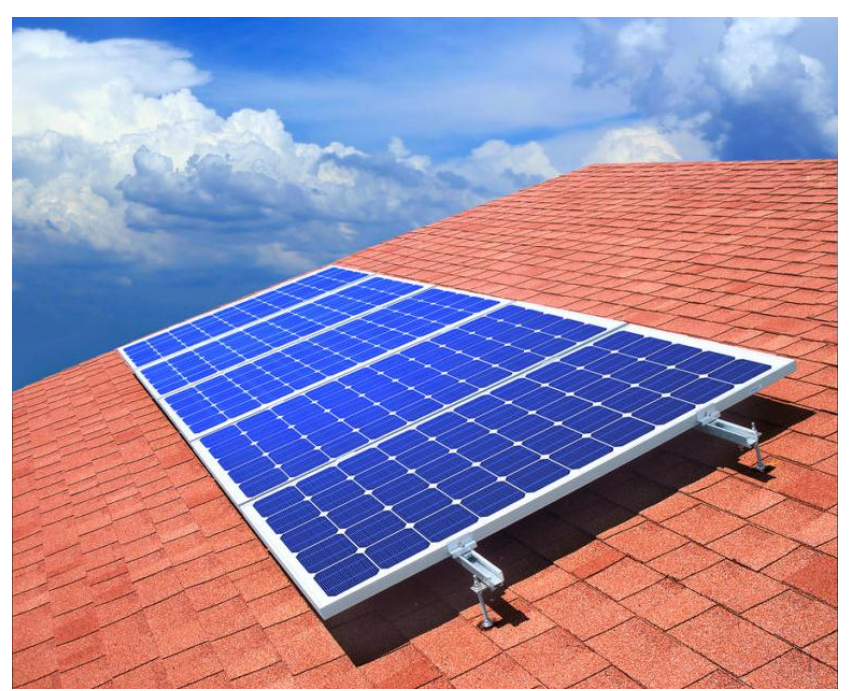

Fig. 1: Installation of solar panels on the roof.

and trees, or lower installed cost, roofs are the default location for residential solar-electric systems. (Figure 1). For the efficiency of solar panels ease of installation and orientation is important, since modules produce greater power the more perpendicular they are to the sun's rays. While the vagaries of residential construction lead to roofs of myriad shapes and sizes, most roofs are designed with a pitch (slope). As one of the roof elements composite skin panels can be used.

\section{Design of Composite Skin Panel}

Typical two-sided composite (timber and plywood) skin panel is used as a roof member for different types of roofing materials. Top and bottom skins of panel is plywood and webs of panel is timber. The usage of this type of roof members for the installation of solar panels have design advantages.

Usually fastening the rails is done using L-feet elements (Figure 2), but in this case it is possible to fasten directly to the webs of panel. If the distance between the webs coincides with the distance of fastening rails of the solar panel, then it's a good transfer of load (Figure 3).

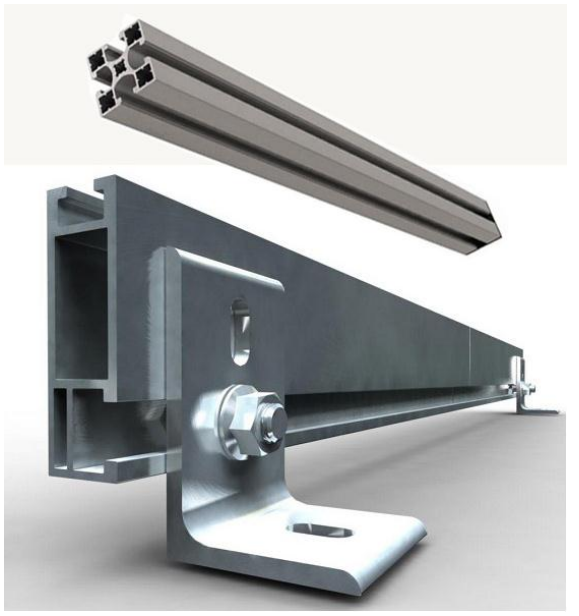

Fig. 2: Fastening the rails with L-feet elements. 

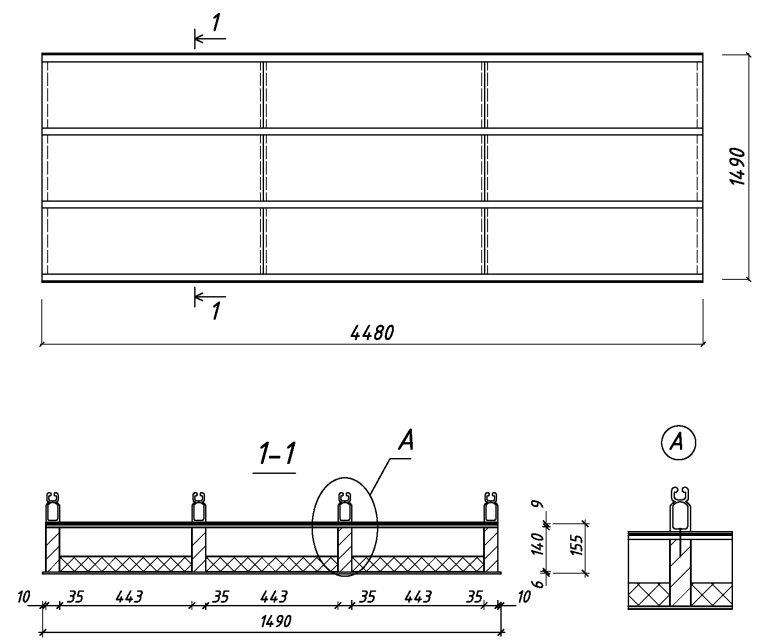

Fig. 3: The two-sided composite skin panel with fastening rails for solar panel.

\subsection{Design Data for the Panel}

For Poltava Region (Ukraine) two-sided composite (timber and plywood) skin panel was designed. Top skin of panel is plywood with thickness $\delta_{t}=9 \mathrm{~mm}$, bottom skin of panel is plywood with thickness $\delta_{b}=6 \mathrm{~mm}$. Spanning between two supports $L=4,5 \mathrm{~m}$ apart (Figure 4). Nominal wide of panel $-b=1,5 \mathrm{~m}$. Construction sizes for panel $149 \times 448 \mathrm{~cm}$.

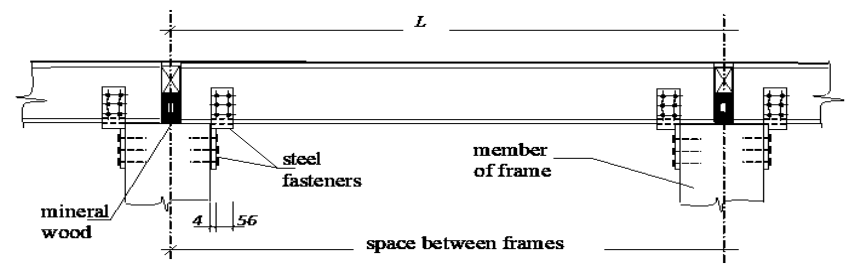

Fig. 4: Fastening composite skin panel to timber members of frame.

The following loads were used, - dead load to the panel and variable loads to the panel (snow load). The wind load is not taken.

\begin{tabular}{|l|l|c|c|c|}
\hline \multicolumn{1}{|c}{ Table 1: Dead load to the $m^{2}$ of panel } \\
\hline \multicolumn{1}{|c|}{ Materials } & $\begin{array}{c}\text { Characteristic } \\
\text { load, } \\
q_{0}, \kappa H / m^{2}\end{array}$ & $\begin{array}{c}\text { Exploitation } \\
\text { load, } \\
q_{e}, \kappa H / m^{2}\end{array}$ & $\begin{array}{c}\text { Safety } \\
\text { factor, } \\
\gamma_{M}\end{array}$ & $\begin{array}{c}\text { Design } \\
\text { load, } \\
q, \kappa H / m^{2}\end{array}$ \\
\hline $\begin{array}{l}\text { 1. Solar panel } \\
\text { 2. Rolled roofing } \\
\text { materials }\end{array}$ & 0,2 & 0,2 & 4 & 5 \\
$\begin{array}{l}\text { 3. Plywood skin } \\
\text { 4. Timber web }\end{array}$ & 0,15 & 0,1 & 1,2 & 0,24 \\
5. Mineral wool in & 0,07 & 0,1 & 1,2 & 0,18 \\
panel & 0,060 & 0,07 & 1,1 & 0,11 \\
6. PE steam insu- & 0,005 & 0,060 & 1,2 & 0,08 \\
lation & & 0,005 & 1,1 & 0,006 \\
Total dead load & & & & \\
for panel- qd & 0,585 & 0,585 & & 0,688 \\
\hline
\end{tabular}

Exploitation snow load $S_{e}$ and design snow load $S_{m}$ set by National Norm.

Table 2: Total loads to the $m^{2}$ of panel

\begin{tabular}{|c|l|l|l|}
\hline \multicolumn{1}{|c|}{ Type of load } & $\begin{array}{l}\text { Characteristic } \\
\text { load, } \\
q_{0}+S_{0}, \\
k N / m^{2}\end{array}$ & $\begin{array}{l}\text { Exploitation } \\
\text { load, } \\
q_{e}+S_{e}, \\
k N / m^{2}\end{array}$ & $\begin{array}{l}\text { Design load, } \\
q+S_{m}, \\
k N / m^{2}\end{array}$ \\
\hline 1 & 2 & 3 & 4 \\
\hline $\begin{array}{l}\text { 1. Dead load to the } \\
\text { panel } \\
\begin{array}{l}2 . \text { Variable loads to } \\
\text { the panel (snow) }\end{array}\end{array}$ & 0,585 & 0,585 & 0,688 \\
Total loads for panel- & 1,450 & 0,710 & 1,508 \\
\hline
\end{tabular}

\begin{tabular}{|l|l|l|l}
\hline $\mathrm{g}_{\text {panel }}$ & 2,035 & 1,295 & 2,196 \\
\hline
\end{tabular}

\subsection{Design Cross-Section of Panel}

Design spacing between webs set for wide $b=100 \mathrm{~cm}$ :

$$
a_{d} \leq \frac{4 \cdot b \cdot \delta_{t}^{2} \cdot f_{m, d}}{3 \cdot P},
$$

were $f_{m, d}-$ design bending strength;

$\delta^{2}{ }_{t}$ - thickness of the top plywood skin

$P$ - live load from weight of man.

And then, panel comprises 4 timber webs. Thickness of web is

$35 \mathrm{~mm}$ after planning (40 $\mathrm{mm}$ - dimensions of sawn timber).

The distance between axis of webs:

$a=\frac{147-3,5}{3}=47,8 \mathrm{~cm}$

The clear distance between webs:

$a_{1}=44,3 \mathrm{~cm}$

Design depth of panel:

$h_{d}=2,2 \cdot L+0,9 \cdot S_{e} \cdot(L-1)$.

were $S_{e}$ - exploitation snow load;

$L=4,5 m$ - space between frames.

Depth parameters of cross-section $\left(h \geq h_{d}\right)$ :

$h=h_{w}+\delta_{t}+\delta_{b}$

were $h_{w}$ - depth of web after planning of sawn timber.

\subsection{Cross-Section Geometric Properties of Panel}

A cross-section of two different materials it is convenient to go transformed section (fictitious section), as shown in Figure 5.

Coefficient for transformed section, as ratio of modulus:

$n_{E}=E_{0} / E_{p l, 0}$.

Areas of cross-sections flanges:

flange in compression-

$A_{p l}{ }^{t}=b_{e f}{ }^{t} . \delta^{t}$

flange in tension-

$A_{p l}^{b}=b_{e f}^{b} \cdot \delta^{b}$,

were $b_{e f}$ - design wide set as $b_{e f}=0,9 . b$.

Area of webs:

$A_{w}=n \cdot b_{w} \cdot h_{w}$

were $n$ - number of webs.

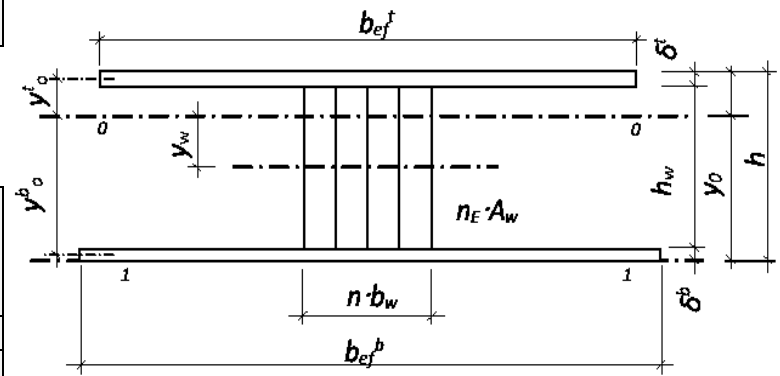

Fig. 5: Transform cross-section as I-beam.

Area of transformed cross-section: 


$$
A_{p l, e f}=A_{p l}{ }^{t}+A_{p l}{ }^{b}+n_{E} \cdot A_{w}
$$

First moment of area of the cross-section about bottom face 1-1:

$S_{p l, e f}{ }^{l}=0,5 \cdot \delta^{b} \cdot A_{p l}^{b}+\left(\delta^{b}+h_{w}+0,5 \cdot \delta^{t}\right) \cdot A_{p l}{ }^{t}+\left(\delta^{b}+0,5 \cdot h_{w}\right) \cdot n_{E} \cdot A_{w}$.

Neutral axis depth from bottom face:

$y_{0}=S_{p l, e f} / A_{p l, e f}$.

Second moment of area of the cross-section about Neutral axis

$I_{p l, e f}=A_{p l}^{b} \cdot\left(y^{b}{ }_{o}\right)^{2}+A_{p l}{ }^{t} \cdot\left(y_{o}^{t}\right)^{2}+n_{E} \cdot\left(A_{f t} \cdot y_{w}{ }^{2}+I_{w}\right)$,

were

$y_{p}=y_{0}-0,5 \cdot h_{p}-\delta^{H}$.

Second moment of area of the web:

$I_{w}=n \cdot b_{w} \cdot h_{w}{ }^{3} / 12$

Transformed modulus of section:

flange in compression -

$W_{p l, e f}{ }^{t}=I_{p l, e f} /\left(h-y_{0}\right)$

flange in tension -

$W_{p l, e f}^{b}=I_{p l, e f} / y_{0}$

\subsection{Bending Stress Check in the Members of Panel (ULS)}

Bending stress (compression) in the top flange:

$\sigma_{c}=M_{d} /\left(W_{p l, e f}^{B} \cdot \varphi_{c, p l}\right) \leq f_{c, 0, d}$,

were

$M_{d}-$ design bending moment;

$f_{c, O, d}$ - design compressive strength of plywood;

$\varphi_{c, p l}=1-\left(a_{1} / \delta^{t}\right)^{2} / 5000$.

Bending stress (tension) in the bottom flange:

$\sigma_{t}=M_{d} / W_{p l, e f}^{b} \leq f_{t, 0, d}$

were $f_{t, 0, d}-$ design tension strength of plywood.

Shear stress at the flange across the glue line:

$\tau_{V}=V_{d} . S_{p l, e f}^{t} / I_{p l, e f} \cdot b_{w} \cdot n \leq f_{V, 0, d}$

were $f_{V, 0, d}$ - design shear strength of plywood;

$V_{d}$ - design shear force;

$S_{p l, e f}{ }^{t}$ - first moment of area of the top flange about Neutral Axis.

$S_{p l, e f}{ }^{t}=A_{p l}{ }^{t} \cdot y^{t}{ }_{o}=A_{p l}{ }^{t}\left(h-y_{o}-\delta^{t} / 2\right)$

\subsection{Deflection Check of Panel (SLS)}

The net final deflection:

$w_{n e t, f i n} / l=5 \cdot q_{l}^{e} \cdot \gamma_{n} \cdot l^{3} /\left(384 \cdot E_{p l} \cdot I_{p l, e f}\right) \leq\left[w_{n e t, f i n} / l\right]$, were

$\left[w_{\text {net, fin }} / l\right]-$ limit value of deflection,

$\gamma_{n}$ - safety factor depending on the class of building and class of structure members.

\section{Conclusion}

A typical double-sided composite (wood and plywood) skin panel is used as a lightweight roof element. Installation of solar panels to this type of roof elements is not difficult. If the distance between the webs of panel is coincide with the distance of fastening rails the solar panel, then is possible to fasten rails directly to the webs of panel. In this case it's a good transfer of load. For design crosssection of composite panel, you can apply a simple method of fictitious cross-section.

\section{References}

[1] APA (1990), Design and fabrication of plywood stressed-skin panels, Supplement 3, Form No. U813L. Tacoma, Washington, USA

[2] Arons, D. M. (2000), Properties and applications of double-skin building facades. Thesis (S.M.), Massachusetts Institute of Technology, Boston.

[3] APA (2014), Plywood design specification. design and fabrication of plywood stressed-skin panels, Supplement 3-12, Form No. U813M. Tacoma, Washington, USA.

[4] .Raadschelders JGM, Blass HJ (1995), Stressed skin panels. STEP 1. Timber engineering. Basis of design, material properties, structural components and joints. Lecture B10, Centrum Hout, Netherland.

[5] Gagnon S, Popovski M (2011), Structural design of crosslaminated timber elements, CLT handbook, Chapter 3, FP innovations Special Publication SP-528E, Quebec, Canada

[6] Blass H, Fellmoser P (2004), Design of solid wood panels with cross layers, In: Proceedings of the 8th world conference on timber engineering (WCTE), vol 2, Lahti, Finland, pp 543-548.

[7] EOTA (2000), Test methods for light composite wood-based beams and columns. TR002, European Organization for Technical Assessment, Brussels, Belgium.

[8] EOTA (2005), Calculation models for prefabricated wood-based load-bearing stressed skin panels for use in roofs, TR019, European Organization for Technical Assessment, Brussels, Belgium.

[9] Forest Products Laboratory (2010), Wood handbook: wood as an engineering material, chap. 5. USDA Forest Service, Madison.

[10] Gaspar F, Cruz H, Gomes A (2008) Evaluation of glued laminated timber structures - core extraction and shear testing. In: Proceedings of the world conference on timber engineering (WCTE), Miyazaki, Japan, pp 255-262.

[11] Werner Weiss, Solar heating systems for houses: a design handbook for solar combisystems, London: James \& James, (2003).

[12] Munari Probst MC, Roecker C (2012), Innovative solar products for building integration, Solar energy and Architecture T.41.A.6 of IEA SHC 41

[13] Roberts S, Guariento N, (2009). Building integrated photovoltaics: a handbook, Basel, Walter de Gruyter.

[14] Munari Probst MC, Roecker C (2014), Designing solar thermal systems for architectural integration, Solar energy and Architecture, Deliverable T.41. A.3 of IEA SHC 41.

[15] https://unirac.com/ 